\title{
A New Mangrove Associated Species Record (Conocarpus L. -Combretaceae) from Tamil Nadu
}

\author{
Vijayakumar Dhaarani ${ }^{1}$, Arumugam Rajendran ${ }^{1 *}$, Ariyan Sarvalingam² \\ 'Department of Botany, Phytodiversity Research Laboratory, Bharathiar University, Coimbatore, Tamil Nadu, India, ${ }^{2}$ Department of \\ Botany, Sri Kaliswari College, Sivakasi, Tamil Nadu, India
}

Received: 19.07.2017

Accepted: 18.09.2017

Published: 26.09.2017

*Address for correspondence:

Arumugam Rajendran,

Department of Botany,

Phytodiversity Research

Laboratory, Bharathiar

University, Coimbatore,

Tamil Nadu, India.

E-mail: slvmlingam@gmail.

com

\begin{abstract}
The genus Conocarpus L., (Combretaceae) a naturalized mangrove genus of India, is reported as an addition to the flora of Tamil Nadu. The species Conocarpus erectus L. was known to occur in Western Africa, tropical and subtropical America. A detailed description along with details on habitat, distribution, and photographs and related genus key is provided here.
\end{abstract}

KEY WORDS: Mangrove associate, Combretaceae, New record

\section{INTRODUCTION}

The family Combretaceae belongs to the order Myrtales and comprises 20 genera and 500 species (Heywood et al., 2007; APG III, 2009). The family is distributed throughout the tropics, with some extensions to subtropical and warm-temperate regions (Stace, 2007; Krachai and Pornpongrungrueng, 2015). In the state of Tamil Nadu, the family Combretaceae is represented by 6 genera, namely, Terminalia L., Anogeissus Wall., Calycopteris Lamk., Lumnitzera Willd., Combretum L., and Quisqualis L., subsequently, genus Conocarpus is now added to the Flora of Tamil Nadu, which has not been reported earlier from Tamil Nadu (Henry et al., 1987; Matthew, 1983; 1999; Manickam et al., 2003a; 2004b; Murugan and Gopalan, 2006; Nair and Henry, 1983; Ravikumar et al., 2004; Stephen and Vajravelu, 1999). During the floristic collection trips to coastal regions of Pudukkottai district, Tamil Nadu, an interesting Combretaceae plant with globose fruits have been collected by the author, which on a critical study has been identified as Conocarpus erectus L., belonging to the family Combretaceae. It is native to Nor th America and the shores of tropical America and Africa (Boone, 1988). Previously, this specimen was also been collected in India only from Andhra Pradesh (Nagireddy et al., 2015). Which after through a critical study and identification, it turned out to a new record for the state of Tamil Nadu. A critical examination of the literature revealed that so far this genus and species has not been reported from Tamil Nadu. Therefore, this genus and a species are reported here with description, herbarium image, illustrations, and relevant notes based on collector's information for its identification.

\section{TAXONOMIC DESCRIPTION}

C. erectus L., Ge. Pl. 1753; Exell Fl. of Malesiana, 4: 533-534. 1954; Engl. \& Diels Monogr. Afr. Combretac. 32; Chev. Bot. 259 (Figure 1).

Shrub 1.5-4 $\mathrm{m}$ in height but can become a tree up to $20 \mathrm{~m}$ or more in height, usually has an erect trunk or multiple trunks, branchlets slightly winged, finely appressed pubescent. Leaves spirally arranged, elliptic to lanceolate, Cretaceous to somewhat fleshy, 2-10 cm long, acute at both ends, narrowed to a short-winged biglandular, petiole, 3-9 cm long, 2-3.5 cm broad, glabrous or nearly so, with several pairs of arcuate lateral nerves. The twigs are slender, yellow-green, angled, flattened, or winged. Inflorescences are terminal or axillary, panicles of tiny greenish-white flowers grouped in spheroidal heads 3-5 $\mathrm{mm}$ in diameter, inconspicuous; calyx 4, acute-acuminate, white hairs present outside; petals 0. Stamens 4-5, exerted, much longer than the calyx; anthers dorsifixed, globose-slightly 


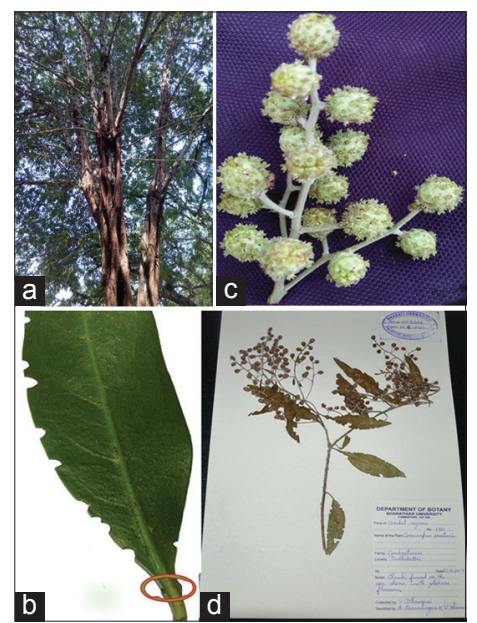

Figure 1: Conocarpus erectus L., (a) habit, (b) leaf with glands present to the base of petiole, (c) inflorescence, and (d) deposited herbarium specimen

angled at the margins. Fruit brownish red, look like old leather buttons and dry, individual fruits (drupes) are 2-winged, overlapping and separating at maturity; twowinged seeds are densely packed into globose clusters.

Fl. and Fr.: Throughout the year.

\section{ECOLOGICAL FUNCTIONS}

The tree is found about $100 \mathrm{mts}$ from the sea in few numbers. The trees now spotted are about 10-15 years old, and the origin of the trees is unknown. Buttonwood is a seaside shrub or tree with highly salt-resistant foliage. It protects the soil during storm surges and helps stabilize dunes. As the trees withstand salt spray, they can be recommended to be planted in the seashore areas to reduce the damages caused by sea intrusion and to prevent soil erosion.

IUCN status: Least concern 2016.3 http:// dx.doi.org/10.2305/IUCN. UK. 2010-2.RLTS. T178806A7612125.en.

\section{ECONOMIC IMPORTANCE}

It is a favorite fuel for smoking fish and makes an excellent firewood emitting very little smoke while burning. It has also been used as a source for charcoal. The wood is heavy and durable in water, making it useful for boats, barges, and other maritime construction. Although very durable, the wood is susceptible to attack by dry wood termites. The plant is used as folk remedy in anemia, catarrh, conjunctivitis, gonorrhea, diabetes, diarrhea, fever, headache, bleeding, tumors, orchitis, prickly heat, swellings, and syphilis (Bashir et al., 2015). Buttonwood has been used as an astringent and as a folk remedy for many ailments (Brown, 2011). Natural products assume an imperative part in the treatment of various infections. The history of utilization of plants to various conditions is extremely old. The foremost records discovered demonstrate that plants have been utilized in Mesopotamia and Egypt thousands of years ago (Hussein, 2016).

Although the previous reports state that the tree has a varied economic and ethnobotanical uses in different countries, the people of the study regions are not aware of the uses of the tree species.

Specimen examined: India: Tamil Nadu (Pudukkottai district). Herbarium deposited by Dhaarani, Sarvalingam, and Rajendran (Bharati-007006), the Department of Botany, Bharathiar University, Coimbatore, Tamil Nadu, India.

\section{CONCLUSION}

The species are found rare in its new habitat in Pudukkottai, Tamil Nadu; it is witnessed that it will take some years to get naturalized in its new habitat, and it is important to create awareness about the plant in the study area as it has many ecological and economic values.

\section{ACKNOWLEDGMENT}

We are grateful to the fisher folks and rural communities of Tranquebar (Tharangambadi), for the cooperation and sharing information during the field trips and the Professor and Head, the Department of Botany, Bharathiar University, Coimbatore, for giving necessary facilities for our research work, and also thanks to Head of the Office, Botanical Survey of India, Southern Regional, Coimbatore.

\section{REFERENCES}

APG, Angiosperm Phylogeny Group III ${ }^{\text {rd }}$. An update of the Angiosperm Phylogeny Group classification for the orders and families of flowering plants: APG III. Bot J Linn Soc 2009;161:105-21.

Bashir M, Uzair M, Chaudhry BA. A review of phytochemical and biological studies on Conocarpus erectus (Combretaceae). Pak J Pharm Res 2015;1:1-8.

Boone RS, Kozlik CJ, Bois PJ, Wengert EM. Dry Kiln Schedules for Commercial Woods-Temperate and Tropical, FPL General Technical Report FPL-GTR-57. Madison, WI: USDA Forest Service; 1988.

Brown SH. U.S. Department of Agriculture, Cooperative Extension Service. Vol. 239. Florida: University of Florida, 
IFAS; 2011. p. 533-7513. Available from: http://www. brownsh@ufl.edu, http: / /www.lee.ifas.ufl.edu/hort/ GardenHome.shtml. [Last accessed on 2017 Jun 30].

Henry AN, Kumari GR, Chithra V. Flora of Tamil Nadu, India, Series-1: Analysis. Vol. 2. Calcutta: Botanical Survey of India; 1987.

Heywood VH, Brummitt RK, Culham A, Seberg O. Flowering Plant Families of the World. London: Royal Botanic Gardens, Kew; 2007.

Hussein RA. Evaluation antioxidant and antibacterial activities of $\mathrm{n}$-butanol fraction of Conocarpus erectus L. leaves extract. Int J Pharm Med Res 2016;4:394-400.

Krachai P, Pornpongrungrueng P. Pollen morphology of Combretaceae from Thailand and its taxonomic significance. Thai Forest Bull (Bot) 2015;43:4-14.

Manickam VS, Sundaresan V, Jothi GJ, Murugan C. Five new records of plants from Tamil Nadu. J Bombay Nat Hist Soc 2004;101:198.

Manickam VS, Jothi GJ, Murugan C, Sundaresan V. Check-list of the flora of Tirunelveli Hills Southern Western, India. Tamil Nadu, India. St. Xavier's College: Centre for Biodiversity and Biotechnology; 2004

Matthew KM. Flora of the Palni Hills, South India. Vol. 1-3.
Tiruchirappalli: The Rapinat Herbarium; 1999.

Matthew KM. The Flora of Tamil Nadu Carnatic. Vol. 1-3. Tiruchirappalli: The Rapinat Herbarium; 1983.

Murugan C, Gopalan R. Three additions to angiosperm flora of Tamil Nadu. J Econ Taxon Bot 2006;30:973-4.

Nagireddy L, Santeiah B, Reddy MS, Parveen SN. Assessment of Urban tree diversity of Kadapa city, Andhra Pradesh. Int J Plant Anim Environ Sci 2015;6:64-7.

Nair NC, Henry AN. Flora of Tamil Nadu, India, Series-1: Analysis. Vol. 1. Calcutta: Botanical Survey of India; 1983.

Pacific Island Ecosystems at Risk, Conocarpus erectus L., Combretaceae; 2002. Available from: http: / / www.hear.org/ pier_v3.3/coere.htm.2p. [Last accessed on 2017 Jun 30].

Pallithanam JP. A Pocket Flora of the Sirumalai Hills, South India. Tiruchirappalli: The Rapinat Herbarium; 2001.

Ravikumar K, Lakshmanan V, Sankar RV. Extended distribution of three Indian endemics in Tamil Nadu. Rheedea 2004; 14:69-70.

Stace CA. The significance of the leaf epidermis in the taxonomy of the Combretaceae I. A general review of tribal, generic and specific characters. Bot J Linn Soc 1965;59:229-52.

Stephen D, Vajravelu E. Additions to the monocotyledonous flora of Tamil Nadu. Indian J Forest 1999;21:367-8.

Author Queries???

AQ1: Kindly cite reference in the text part 